\title{
Örgütsel Yeşil Davranışlara Yönelten Güdüler: Özel Okul Öğretmenleri Üzerine Nitel Bir Araștırma

\author{
(Motives Towards Organizational Green Behaviors: A Qualitative Research on the Private \\ School Teachers) ${ }^{1}$
}

\section{Eylem BAYRAKÇI iD a Mehmet DİNÇ iD $b$}

a Isparta Uygulamalı Bilimler Üniversitesi, Yalvaç Büyükkutlu Uygulamalı Bilimler Yüksekokulu, Uluslararası İşletmecilik ve Ticaret Bölümü, Isparta, Türkiye. eylembayrakci@isparta.edu.tr

b Isparta Uygulamalı Bilimler Üniversitesi, Yalvaç Büyükkutlu Uygulamalı Bilimler Yüksekokulu, Muhasebe ve Finans Yönetimi Bölümü, Isparta, Türkiye. mehmetdinc@isparta.edu.tr

\begin{tabular}{|c|c|}
\hline MAKALE BİLGİSi & ÖZET \\
\hline $\begin{array}{l}\text { Anahtar Kelimeler: } \\
\text { Örgütsel yeşil davranış } \\
\text { İzlenim taktikleri } \\
\text { Prososyal } \\
\text { Yeşil güdü } \\
\text { Nitel araştırma }\end{array}$ & $\begin{array}{l}\text { Amaç - Eğitim yarının dünyasını şekillendirecek ve geleceğin zorluklarıyla baş etmede } \\
\text { faydalanılabilecek en etkili araçlardan biridir. Aynı zamanda eğitim sürdürülebilirliğe yönelik } \\
\text { tutumsal değişimi başlatmada önemli bir role sahiptir. Diğer okullar gibi özel okullar da doğal çevre } \\
\text { üzerindeki baskıyı azaltmada ve çevresel sürdürülebilirliği başarmada temel bir rol üstlenirler. Özel } \\
\text { okulların öğretmenlerinden çevreyi olumlu etkileyecek veya çevreye yönelik olumsuz etkisini } \\
\text { azaltacak yeşil davranışları rol model olma bilinciyle geliştirmeleri ve öğrencilerini etkilemeleri } \\
\text { beklenir. Bu çalışmanın amacı özel okul öğretmenlerini yeşil örgütsel davranışları gerçekleştirmeye } \\
\text { iten güdüleri tespit etmektir. }\end{array}$ \\
\hline $\begin{array}{l}\text { Gönderilme Tarihi } 3 \text { Ağustos } \\
2019 \\
\text { Revizyon Tarihi } 30 \text { Aralık } 2019 \\
\text { Kabul Tarihi } 7 \text { Şubat } 2020\end{array}$ & $\begin{array}{l}\text { Yöntem - Araştırmada nitel araştırma yöntemi kullanılmış ve iki ayrı ilde faaliyet gösteren üç farklı } \\
\text { özel okulda görev yapan } 20 \text { öğretmen ile nitel görüşmeler yapılmıştır. Katılımcıların } \\
\text { belirlenmesinde kartopu örneklem yöntemi kullanılmış, görüşmeler yüz yüze yapılmış ve } \\
\text { görüşmelerin analizinde Maxqda } 2018 \text { nitel veri analiz programı tercih edilmiştir. }\end{array}$ \\
\hline Makale Kategorisi: & $\begin{array}{l}\text { Bulgular - Araştırmanın sonucunda, dört temada toplanabilen güdülerin (izlenim yönetimi } \\
\text { güdüleri, yeşil güdüler, prososyal güdüler ve örgütsel vatandaşlık güdüleri) öğretmenleri yeşil } \\
\text { örgütsel davranışa yönlendirdiği bulunmuştur. }\end{array}$ \\
\hline Araştırma Makalesi & $\begin{array}{l}\text { Tartışma - Öğretmenler izlenim yönetimi güdüleri kapsamında ekseriyetle öğrencileri üzerinde } \\
\text { “örnek davranışlar sergileme" taktiği biçiminde, veliler üzerinde ise "kendini sevdirme" taktiği } \\
\text { biçiminde yeşil örgütsel davranışları sergilemişlerdir. Ayrıca, çevresel sürdürülebilirlik kaygılarının } \\
\text { yeşil güdü olarak, toplumsal ve sosyal fayda sağlamanın prososyal güdü olarak yeşil örgütsel } \\
\text { davranışları etkilediği bulunmuştur. Bazı öğretmenlerce yeşil davranışlar sergilemenin örgütsel } \\
\text { vatandaşlık davranışı olarak algılandığı sonucuna ulaşılmıştır. }\end{array}$ \\
\hline
\end{tabular}

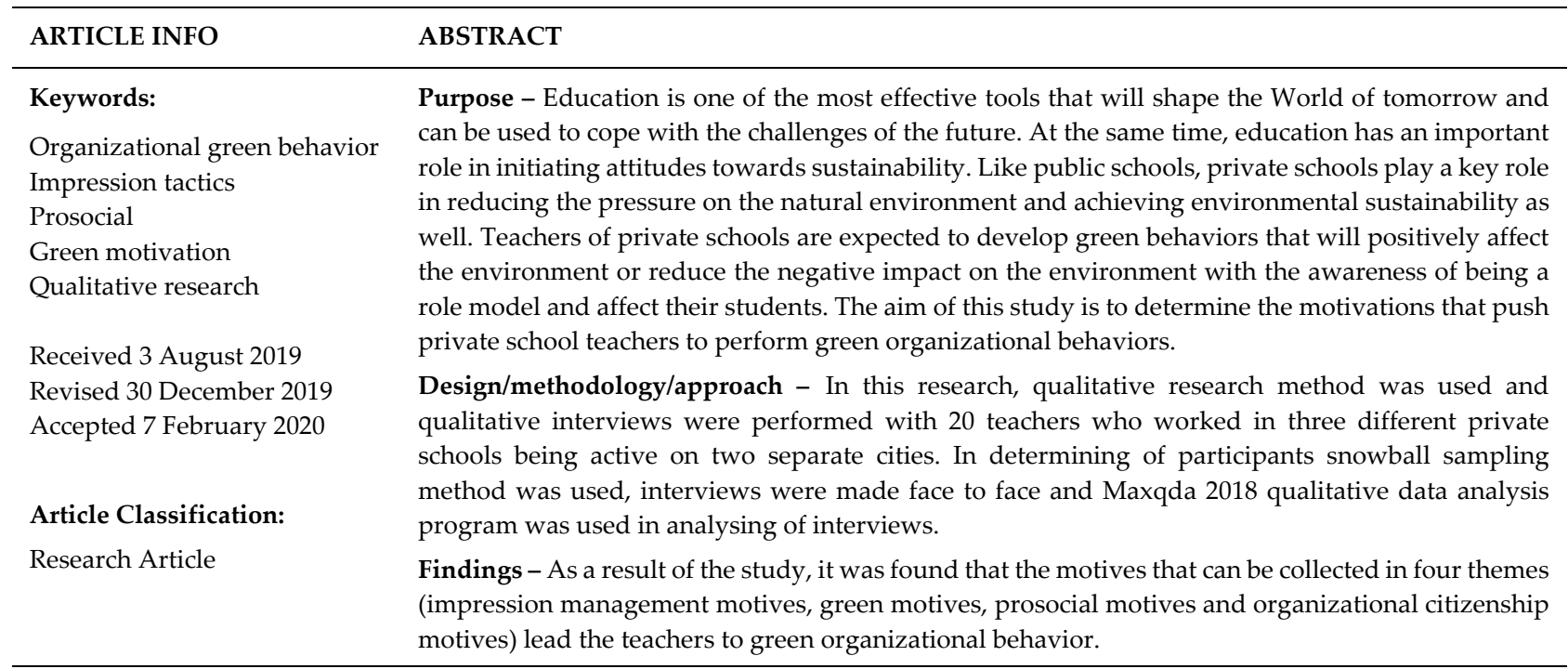

\footnotetext{
${ }^{1}$ Bu çalışma 04-06 Eylül 2018 tarihinde Roma/İtalya'da düzenlenen VI. International Multidisciplinary Congress of Eurasia'da sözlü bildiri olarak sunulan çalışmanın genişletilmiş halidir. 
Discussion - Within the scope of impression management motives, teachers mostly displayed "exemplification" tactics on their students and displayed green organizational behaviors as "ingratiation" tactics on the parents. In addition, environmental sustainability concerns as a green motivation and social benefit have influenced green organizational behavior as a prosocial motive while at the same time some participants have perceived green behavior as organizational citizenship behavior.

\section{Giriş}

Çevresel sürdürülebilirlik günümüzün ilgi çekici ve tartışmaya değer bir konusu haline gelmiştir. Zira içinde bulunulan çağın küresel ve rekabetçi ortamı örgütleri geçmişteki emsallerine göre doğal çevre konusunda daha endişeli ve dolayısıyla daha ilgili hale getirmiştir. Bu örgütlerin paydaşlarının uzun dönemde çevresel kirliliğin ve çevresel bozulmanın sonuçlarına yönelik kaygıları artmıştır. Çevresel sürdürülebilirliğe katkı sağlamak konusunda bir çok paydaştan gelen baskılara maruz kalan işletmeler, yürüttükleri işletmecilik işlemlerinin ayak izlerini azaltma konusuna daha fazla ilgi duymuşlardır. Bu yöndeki ilgi bir yandan örgütleri çevreye yönelik yeşil davranışlarda bulunma konusunda girişimlerde bulunmaya zorlamış ve örgüt çalışanlarının sürdürülebilirlik-temelli girişimlere katılmasını gerekli hale getirmiş (Wiernik vd., 2016: 1), bir yandan da örgütsel uygulamalardan sorumlu uzmanları iş yerinde çevre dostu davranışı cesaretlendirecek önlemler almaya yönlendirmiştir (Norton vd., 2014: 50).

Çevresel sürdürülebilirlik yönünde artan ilgi temelindeki değişim örgütsel bağlama da yansımıştır. Bu değişime örgütsel davranış alanı da kendi dinamikleri çerçevesinde uyum sağlamaya çalışmıştır. Çünkü örgütler girdi, süreç ve çıktılarını çevresel sürdürülebilirliğe ulaşacak şekilde değiştirme eğilimi göstermiş ve değişime destek vermek amaciyla örgütsel bağlamda hem yeni yeşil pozisyonlar eklemiş hem de mevcut işlerin sorumluluk sınırlarını genişleterek yeşil görevleri işlere eklemiştir (Klein, 2015: 1). Örneğin İnsan Kaynakları Yönetimi Derneği'nin (Society for Human Resource Management) (2011) 1705 insan kaynakları uzmanı üzerinde yaptı̆̆ı çalışma bulguları; örgütlerin \%23'ünün yeni yeşil pozisyonlar veya yeni oluşturulan işlere yeşil görevler eklediğini, örgütlerin \%81'inin geçmiş yıllar içerisinde mevcut pozisyonlara yeni görevler eklediğini göstermiştir. Fortune 500 şirketlerini sistematik olarak ele aldığı araştırmasında D'Mello ve arkadaşları (2011), bu şirketlerin \%85'inden fazlasının geri dönüşüm, enerji kullanımını azaltma, kirliliği önleme ve diğer proaktif çabalar gibi çevresel sürdürülebilirlik çalışmaları yürüttüğünü tespit etmiştir. Yine İnsan Kaynakları Yönetimi Derneği (2011) tarafından yürütülen bir diğer araştırma; araştırmaya katılan örgütlerin yaklaşı 2/3'ünün bazı çevresel sürdürülebilirlik çalışmalarında bulunduklarını ve yaklaşık yarısının ise işyeri sürdürülebilirliğini ifade eden biçimsel bir politikaya sahip olduğunu açığa çıkarmıştır.

Örgütlerin yaptığı hiçbir girişimin çalışanlarından bağımsız olarak değerlendirilemeyeceği bilinmektedir. Bu ön kabulden hareketle bazı araştırmacılar (Boiral, Paille ve Raineri, 2015: 13; Aguinis ve Glavas, 2013: 314) yukarıda ifade edilen araştırma sonuçları ile tutarlılık gösterecek şekilde, çalışanlar tarafından yapılan girişimlerin biçimsel yönetim sistemleri, prosedürleri veya teknolojileri tarafından yapılan girişimlerin ötesinde örgütlerin yeşil hale gelmesinde önemli bir etkisi olduğunu belirtmişler, sürdürülebilir işletme başarısına ulaşabilmek için çevresel performansın bireysel ve örgütsel yeşil davranışla iç içe geçmesi gerektiğini vurgulamışlardır.

Yeşil eylemlere yönelik odağın artışıyla beraber kişilerin veya çalışan bireylerin çevreye duyarlı yeşil davranışlarına dair bireysel güdülerini merkeze alan yazın gelişerek devam etmektedir. Yeşil davranışa yönelik bireysel güdülere dayalı araştırmalar yakından incelendiğinde; araştırmaların bir kısmı (Bramston vd., 2011: 778; Ryan vd., 2001: 632) çevresel temsilcilik güdülerine veya çevreye yardım etme davranışlarına odaklanmıştır. Bazı araştırmalar (De Young ve Kaplan, 1986: 223; Lee vd., 1995: 380) iş ortamında çalışanlar ve hane halkı açısından yeşil davranmaya yönelik bireylerin güdülerini incelemiştir. Bir diğer araştırma grubu (Ones ve Dilchert, 2012b: 444; Bansal ve Roth, 2000: 717) örgütlerin niçin sürdürülebilir ve yeşil davranış girişimlerinde bulunduğuna veya bu girişimlerden kaçındığına dair güdüleri incelemiştir. Bazı araştırmalar (Kim vd., 2017: 1335; Bissing-Olson vd., 2013: 157) ise yeşil davranış güdülerine yönelik bireysel farklılıklara odaklanmıştır. Bu araştırmacılara göre güdülemeye dair bireysel farklılıklar; kişilerin ilgi alanları, yetenekleri, kişilik özellikleri ve deneyimleri gibi davranışlarında farklı oldukları görüşünü temsil etmiştir.

Yukarıda bahsedilen araştırma bulgularından hareketle, kurumsal çevresel sürdürülebilirliğe odaklanan araştırmaların birey düzeyinde çalışan davranışlarını merkezlerine aldığı söylenebilir. Bu yöndeki bireysel çalışan düzeyinin özel okul öğretmenlerini de içerdiği öne sürülebilir. Dolayısıyla çevreye yönelik 
sürdürülebilir kararlar almanın ve bu yönde davranışlar geliştirmenin hissedildiği alanlardan birinin de özel okullar gibi eğitim kurumları olduğu görülmektedir. Eğitim kurumları, bireylere yönelik öğretimsel veya eğitimle ilgili hizmetler sunan örgütler olarak tarif edilmektedir (OECD, 2002: 64). Özel okullar, bütünüyle veya kısmen devam eden öğrenciler tarafından bütçelenen eğitim kurumu türüdür ve işletmelere benzer şekilde faaliyet gösterirler. Özel okullar bir ürün sunarlar, öğrencilerine ve ailelere sunulan eğitimi artırmayı amaç edinirler. Bu hizmetleri kapsamında öğretmenlere, destek personeline, işletme yöneticilerine, muhasebecilere, antrenörler ve danışmanlara istihdam fırsatı sağlarlar. Diğer işletmeler gibi özel okullar da işlerini yürütürken bir çok maliyet kalemiyle (enerji maliyeti, kaynaklar, işgücü ücretleri ve bakım ücretleri gibi) karşılaşırlar. Diğer işletmeler gibi özel okullar sürüdürülebilir bir örgüt olmak isterlerse, çalışanlarının ve özellikle öğretmenlerinin yeşil davranışlarını teşvik etmeye gereksinim duyarlar (Benn vd., 2014: 3).

Yazından elde edilen bulgular örgütsel alanın çalışanların yeşil davranışlarını sergileme yeterliliklerini etkilediğini göstermiştir. İşyerindeki dinamiklerin çalışanların yeşil davranışlarına etkisini aynı örgütte farklı roller yerine getirme esnasında çalışanları farklı biçimde etkileyebilmektedir. Örneğin eğitim sektörü (özel okullar vb. gibi) aynı örgüt içinde öğretmen, ofis temelli roller, yönetim gibi çok farklı iş türü aralığından oluşur. Bununla birlikte, eğitim alanında çalışan yeşil davranışları performansını iceleme konusunda bir açıklığın olduğu görülmektedir. Yürütülen bazı çalışmalar (Boiral ve Paille, 2012) lisans ve lisansüstü öğrencileri katılımcı olarak seçmiştir. Böylece bu çalışma, özel okul öğretmenlerini katılımcı olarak tercih etmiş ve ifade edilen boşluğu doldurmayı hedeflemiştir.

Ayrıca uluslararası akademik yazında örgüt üyelerinin yeşil davranışları ile ilgili yapılan çalışmalar olduğu görülmektedir. Bununla birlikte ulusal yazında konunun oldukça yeni olduğu, bu konuda sınırlı sayıda çalışma yapıldığı görülmekte ve daha fazla çalışma yapılmasına ihtiyaç olduğu görülmektedir. Dedeoğlu ve arkadaşları (2016: 38) örgütsel davranış disiplininin mevcut durum ve geleceği ile ilgili yaptıkları çalışmalarında örgütsel davranış alanında geliştirilmeyi bekleyen başlıca çalışma alanlarını sıralamışlar ve bu sıralamada yeşil örgütsel davranışları ilk sırada ifade etmişlerdir. Tüm bu ve yukarıda belirtilen tespitlerden hareketle, çalışma özel okul öğretmenlerinin yeşil örgütsel davranışlar gerçekleştirmesine neden olan güdülerin neler olduğunu katılımcıların bakış açısıyla ortaya çıkartabilmeyi amaçlamıştır. Bu amaca ulaşabilmek için eğitim sektörü kapsamında özel okullar tercih edilmiş ve özel eğitim kurumlarında görev yapan öğretmenlerin görüşleri ışığında nitel araştırma yürütülmüştür.

\section{Kavramsal Çerçeve}

Son dönemlerde çalışma ortamında belirli bir bağlam içinde yeşil davranışı anlamanın önemli hale geldiğini vurgulayan bir anlayış gelişmiştir. Bu anlayışın nedenlerinden birincisi, örgütlere yönelik çevresel kaygıları gidermede örgütlerin tepki vermeleri ve sürdürülebilir olmaları yönünde sosyal, normatif ve düzenleyici kaynaklardan gelen baskılarda bir artışın yaşanmasıdır (Norton vd., 2015: 103). İkincisi, yürütülen çalışmalardan elde edilen bulguların çevresel uygulamalardaki başarı ve başarısızlığın çalışan davranışından kaynaklandığını teyit etmesidir (Bartlett, 2011: 1).

Çevresel davranışların örgüt içinde tanımlanmasının gerektiğinden hareketle bazı araştırmacılar bu kavramı tanımlamışlar ve kavramı çok boyutlu olarak ele alarak kavramın farklı noktalarını vurgulamışlardır (Ones ve Dilchert, 2012a; Mesmer-Magnus vd., 2012; Ramus ve Steger, 2000). Ones ve Dilchert (2012a: 87) çalışan yeşil davranışları; çevresel sürdürülebilirliğe katkı sağlayan veya çevreye verilecek zararlara engel olan çalışanların sergilediği ölçülebilir eylemler ve davranışlar biçiminde tanımlamıştır. Bu tanımlamalarında araştırmacılar; sadece çalışanlara odaklanma, kişilerin kontrolleri altındaki eylemler, ölçülebilir eylemler ve hem yararlı hem de zararlı davranışların entegrasyonu şeklindeki dört unsuru kavramın tanımlanmasında öne çıkarmışlardır. Pro-çevresel davranışın işyerine özgü bir şeklini ifade eden çalışan yeşil davranışı, örgütsel çevresel sürdürülebilirliğin gerekli bir bileşeni olarak da görülmektedir (Ones ve Dilchert, 2012b: 452).

Mesmer - Magnus ve arkadaşları (2012: 169) işyerinde çalışan yeşil davranışın bir başka tanımını; çevresel sürdürülebilirliğe katkı sağlayan bireylerin tüm davranışları olarak önermiştir. Dolayısıyla böylesi davranışlar bireylerin kontrolleri altındaki seçimsel, niyetsel ve pro-aktif nitelikteki davranışlara vurgu yapar.

Çalışanların yeşil davranışlarının tanımlanmasında eko-girişimler kavramının da göz önüne alındığı görülmektedir. Ramus ve Steger'e (2000: 606) göre eko-girişim; eko-yenilikçiliğe yakın bir kavramdır ve işletmesinin çevresel performansını iyileştirebileceği düşüncesiyle bir çalışanın yaptığı eylem anlamına gelir. 
Dolayısıyla geri dönüşüm, kirliliği önleme, zararlı atıkları azaltma ve çevreyle ilgili etkililiği iyileştirme gibi davranışlar bu tanıma uygun örnekleri temsil eder.

Yazında çalışanın rolünün bir parçası olarak gerekli/zorunlu davranışları ile gönüllü davranışları arasında bir ayrım yapılmasının gerekli olacağına dikkat çekilmektedir (Bissing - Olson vd., 2013: 157-158). Genelde çalışma ortamında yeşil davranışa odaklı çalışmalar (Paille ve Boiral, 2013: 119; Ramus ve Steger, 2000: 606) bu kavramı gönüllü davranış şeklinde ele almışlardır. Ancak örgütün psikolojik yanlarına odaklı çalışmalar yürüten araştırmacılar, çalışan tüm yeşil davranışlarının sağduyusal (discretionary) olmadığını ve gönüllülük dışında da ele alınabileceğini iddia etmiş̧lerdir (Ones ve Dilchert, 2012a: 87).

Zorunlu çalışan yeşil davranış, çalışanların yapmak durumunda olduğu iş yükümlülükleri bağlamında yürütülen yeşil davranışı ifade eder (Bissing - Olson vd., 2013: 157) ve görev performansına (Borman ve Motowidlo, 1993: 73) benzerlik gösterir. Zorunlu yeşil davranış kapsamında; örgütsel politikalara bağlllık, sorumlu seçeneklerin seçimini içeren iş/çalışma yöntemlerini değiştirme, sürdürülebilir ürün ve süreçler oluşturma sayılabilir. Gönüllü çalışan yeşil davranış; örgütsel beklentileri aşan bireysel girişimi içeren yeşil davranış olarak tanımlanır (Bissing - Olson vd., 2013: 158) ve iş performansının yapıldığı sosyal ve psikolojik ortamı destekleyen davranışı ifade eden bağlamsal performans ve örgütsel vatandaşlık davranışı (Borman ve Motowidlo, 1993: 73; Organ, 1997: 88) kavramlarına yakınlık taşır. Gönüllü çalışan yeşil davranış kapsamında; çevresel yararlara öncelik vermek, çevresel program ve politikaları başlatmak, lobi ve aktivist faaliyetler yürütmek ve diğer kişileri teşvik etmek sayılabilir.

Çalışan yeşil davranışının çok boyutlu yönünü yansıtmak amacıyla birçok sınıflandırma yazındaki yerini almıştır. Bu noktadaki en kapsamlı olan sınıflandırma Ones ve Dilchert (2012a) tarafından önerilen beş yeşil sınıflandırmadır. Araştırmacıların önerdiği Beş Yeşil Davranış kategorisi şu şekildedir:

Sürdürülebilirlik Temelli Çalışma Kategorisi, daha sürdürülebilir olan iş süreçlerine ve ürünlere yardımcı olan davranışları temsil eder. Zarar Vermekten Kaçınma Kategorisi, ya dünyaya zarar veren ve zararların artışına sebep olan ya da ekosistemi daha sağlıklı yapacak şekilde dünyayı değiştiren davranışlardan oluşur. Koruma Kategorisi, kaynakları artırmaya ve israfı azaltmaya yardım eden davranışları ifade eder. Olumlu örnek olarak çift sayfalı çıktı almak ve olumsuz örnek olarak bilgisayarı tüm gece boyunca açıkta bırakmak verilebilir. Diğer Kişileri Etkileme Kategorisi, bireysel anlamda çalışanın neyi başarabileceğinden çevresel davranışlarda bulunması için bireylerin birbirini nasıl etkileyebileceğini ifade eder. Psikolojik olarak bu üst kategori, bilgiyi yayma davranışlarını değiştirmede diğer kişilere yardım etmeyle ilişkilidir. İnisiyatif Kullanma/Girişimde Bulunma Kategorisi, risk alma ve çevre ile ilgili değişimleri cesaretlendirmeyi gerektiren davranışları anlatır.

Ones ve Dilchert (2012a: 92) ayrıca Yeşil Beş'in daha yüksek düzeyde proaktif ve reaktif olmak üzere iki temel faktöre ayrıldığını da belirtmişlerdir. Proaktif faktör, çevreyi aktif biçimde iyileştiren veya zarardan önleyen inisiyatif kullanma/girişimde bulunma, diğer kişileri etkileme ve sürdürülebilir biçimde çalışma boyutlarını içerir. Reaktif faktör ise, koruma ve zarar vermekten kaçınma boyutlarını kapsar.

Çalışan yeşil davranışıyla ilgili bir diğer sınıflandırma, pro-çevresel davranışın etkilerini, etkinliklerini veya sıklığını ortaya koymaya yönelik önerilerden birisini temsil eden Smith ve O'Sullivan'a (2012: 470) aittir. Çevresel olarak sorumlu işyeri davranışı sınıflandırması olarak bilinen ve farklı davranış türlerini kategorileştiren bu sınıflama iki ana boyuta ayrılır. Bu boyutlar;

- Doğrudan Davranışa (geri dönüşüm kutuları gibi bireyin kendi eylemlerine dayalı) karşıt Dolaylı Davranış (çevresel bir evrakı imzalama gibi diğerlerini etkileyen eylemler),

- Yerel Etkiye (örneğin çalışma ortamında gereksiz ışıkları kapatmak gibi yerel davranışı artırma) karşıt Geniş Etki (yeni çevresel yönetim uygulamaları başlatmak gibi).

Bazı araştırmacılar (Homburg ve Stolberg, 2006: 7) çalışan yeşil davranışının doğrudan ve dolaylı olabileceğini de savunmuştur. Doğrudan örgütsel yeşil davranış, çevreyi iyileştirmeye yönelik kesin/somut jestler sergilemeyi ifade ederken (geri dönüşüm gibi); dolaylı örgütsel yeşil davranış ise, çalışma ortamında doğrusal örgütsel yeşil davranışını benimsemede diğer bireylere öneri veya cesaretlendirme sağlamaya dair çalışanın güdüleme faaliyetlerini ifade eder.

Yazında insanların niçin örgütsel bağlamda yeşil davranışlar sergilediğini, bu davranışların belirleyici faktörlerini veya öncüllerini açıklamak amacıyla bu konudaki bulguları analiz eden çalışmalar yürütülmüştür. 
Blok ve arkadaşları (2015: 56-57) örgütsel yeşil davranışların öncüllerinin demografik, içsel ve dışsal faktörler olmak üzere üç grupta inceleneceğini ifade etmiştir. İçsel faktörleri; sosyal faktörler (sosyal normlar, kişisel normlar), bilişsel faktörler (çevresel farkındalık, eylem niyeti, algılanan davranışsal kontrol) ve duygusal faktörler (değerler, çevreye yönelik tutum) olarak tanımlamışlardır. Dışsal faktörler, işyeriyle ilişkili olan ortamsal faktörlerden ve liderlik desteğinden oluşmuştur.

Lo, Peters ve Kok (2012: 227) örgütsel yeşil davranışın öncüllerini ele alan çalışmaları analiz ederek bu tür davranışların gerçekleşmesini sağlayan bireysel ve örgütsel belirleyicileri tespit etmişlerdir. Araştırmacılar bireysel öncülleri; niyetler, tutumsal belirleyiciler, sosyal normlar, öz-yeterlilik ve geçmiş davranışın oluşturduğunu tespit etmiştir. Onlar örgütsel öncüller arasında ise; genel örgütsel belirleyicilerin (yönetime duyulan güven, katılımcıların duygusal bağlılığı, yöneticinin çevresel destek davranışı, örgüt kültürü, örgütsel yapı), çevresel politikaların, üstlerin çevreyle ilgili katılımının, fiziksel imkânların ve çevresel ölçümlerin meşruluğunun sayılabileceğini belirtmişlerdir.

\section{Yöntem}

Çalışmada nitel araştırma yöntemi tercih edilmiştir. Çalışmanın yazın bölümünde söz edildiği gibi yeşil örgütsel davranışlar sınırlı sayıda araştırmaya konu olmuştur ve örgütsel davranış alanında geliştirilmeyi bekleyen konular arasında yer almaktadır. Bulguların büyük çoğunluğunun ise nicel yöntemlerle elde edildiği görülmektedir. Araştırmada örgütsel yeşil davranışların gerçekleştirilme nedenleri katılımcıların deneyimlerinden ve algılarından yola çıkılarak açıklanmaya ve yorumlanmaya çalışılmıştır. Böylece katılımcıları belirli ölçeklerle sınırlandırarak ölçeğe uygun hareket edip etmediklerini belirlemek yerine kendi ifadelerinden yola çıkarak çalışanları harekete geçiren güdüler belirlenebilmiştir. Ayrıca, örgütlerde yeşil davranışların özendirilebilmesi için neler yapılabileceği katılımcıların görüşleri doğrultusunda ifade edilmiştir. Ayrıca araştırma konusu olan güdüler ile ilgili yapılmış herhangi bir çalışmaya rastlanılamamıştır. Bu durum çalışmada nitel araştırma yönteminin tercih edilmesinde etkili olmuştur.

Nitel araştırmalar, herhangi bir içerikte veya etkinlikte katılımcılarca oluşturulan anlamları açıklamak ve anlamak için kullanılır (Morrow ve Smith, 2000, alıntılayan Hoş, 2012: 52). Denzin ve Lincoln (2005) "nitel araştırmacılar olguları doğal ortamında çalışırlar ve böylece olguları anlarlar veya insanların onlara ne gibi anlamlar yüklediğini yorumlarlar" söyleminde bulunmuştur (Merriam, 2013: 13).

Araştırmanın amacı; "özel okul öğretmenlerini yeşil davranışlara iten güdülerin ortaya çıartılması" olarak belirlenmiştir. Araştırma amacına bağlı olarak 2 ana araştırma sorusu belirlenmiştir:

AS1. Öğretmenlerin yeşil davranışları gerçekleştirme nedenleri nedir?

AS2. Öğretmenlerin yeşil davranışlarını arttırmak için neler yapılabilir?

\subsection{Katılimcilar}

Araştırmada kartopu örneklem yöntemi kullanılmıştır. Buna göre, iletişimde bulunulan bazı öğretmenlerle görüşülmüş, onların iletişimde bulunduğu ve yönlendirdiği diğer kişilerle görüşmeler yapılmıştır. Katılımcılar iki ayrı ilde faaliyet gösteren üç farklı özel okulun 20 öğretmeninden oluşmaktadır. Bu alanın seçilmesinin nedenlerinden birisi öğretmenlerin çevresel sürdürülebilirliğin gelecek nesillere aktarılmasında önemli bir rol oynaması, diğeri ise öğrencilere örnek teşkil eden öğretmenlerin örgütsel bağlamda yeşil davranışları neden gerçekleştirdiğinin ortaya çıartılmasıdır. Katılımcıların maksimum çeşitliliği yansıtmasına özen gösterilmiştir. Buna göre 13 katılımcı kadın, 7 katılımcı erkektir. Katılımcılar 24-56 yaş aralığındadır ve çalışma süreleri 1 ile 35 yıl arasında değişmektedir. Katılımcılara ait demografik bilgiler Tablo 1'de verilmiştir: 
E. Bayrakçı - M. Dinç 12/1 (2020) 188-201

Tablo 1. Katılımcilara Ait Demografik Bilgiler

\begin{tabular}{|l|l|l|l|l|}
\hline \multicolumn{1}{|c|}{ Katılımc1 } & \multicolumn{1}{|c|}{ Yaş } & \multicolumn{1}{c|}{ Cinsiyet } & \multicolumn{1}{c|}{ Uzmanlık } & Çalışma Süresi \\
\hline Ö1 & 25 & Erkek & Din Kültürü Ve Ahlâk Bilgisi & 3 yıl \\
\hline Ö2 & 28 & Erkek & Bilgisayar ve Ö̆ğretim Teknolojileri & 1 yıl \\
\hline Ö3 & 24 & Erkek & Coğrafya & 1 yıl \\
\hline Ö4 & 34 & Kadın & Yabancı Dil & 12 yıl \\
\hline Ö5 & 38 & Kadın & Yabancı Dil & 15 yıl \\
\hline Ö6 & 23 & Kadın & Bilgisayar ve Öğretim Teknolojileri & 1 yıl \\
\hline Ö7 & 45 & Erkek & Fizik & 21 yıl \\
\hline Ö8 & 36 & Kadın & Coğrafya & 14 yıl \\
\hline Ö9 & 28 & Kadın & Tarih & 1 yıl \\
\hline Ö10 & 34 & Kadın & Türkçe & 10 yıl \\
\hline Ö11 & 28 & Kadın & Fen Bilgisi & 3 yıl \\
\hline Ö12 & 33 & Kadın & Yabancı Dil & 2 yıl \\
\hline Ö13 & 27 & Kadın & Matematik & 4 yıl \\
\hline Ö14 & 39 & Kadın & Sinı Öğretmeni & 2 yıl \\
\hline Ö15 & 25 & Erkek & Türkçe & 6 yıl \\
\hline Ö16 & 29 & Kadın & Sını Öğretmeni & 12 yıl \\
\hline Ö17 & 35 & Kadın & Sını Ö̆ğretmeni & 14 yıl \\
\hline Ö18 & 38 & Erkek & Yaratıcı Drama & 35 yıl \\
\hline Ö19 & 56 & Erkek & Sını Ö̆ğretmeni & 18 yıl \\
\hline Ö20 & 40 & Kadın & Sını Ö̆ğretmeni &
\end{tabular}

\subsection{Araştırma Süreci}

Katılımcılarla Şubat 2018'de 20-36 dakika arasında süren görüşmeler yapılmış ve ses kayıt cihazı ile kayıt altına alınmıştır. Ses kayıtları Word belgesi halinde bilgisayar ortamına aktarılmış ve satır satır okunarak analiz edilmiştir. Verilerin analizinde sistematik ve yorumlayıcı analizler birlikte kullanılmıştır. Görüşmelerin sistematik analizinde Maxqda 2018 nitel veri analiz programı kullanılmıştır. Nitel yöntemle yapılan araştırmalarda bu tür programların kullanılmasının güvenirliği arttırdığı bilinmektedir (Kuş Saillard, 2010: 17). Sistematik analizde, elde edilen veriler içinde yer alan anahtar faktörler ortaya çıkartılmaya ve veriler arasındaki ilişkiler ortaya konulmaya çalışılır (Walcott, 1994 alıntılayan Özdemir, 2010: 331). Katılımcıların görüşmeleri dikkatle birkaç kez okunmuş, ifadeler kodlanmış, anlam ve ilişki bakımından birbirine benzeyen kodlar bir araya getirilerek temalar oluşturulmuştur. Verilerin sistematik analizinden sonra yorumlayıcı analiz ile elde edilen bulgular araştırmacıların konu ile ilgili öznel görüşleri ile yorumlanmıştır.

\section{Bulgular}

Araştırmada elde edilen bulgular daha önce ana hatlarıyla verilen araştırma soruları referans alınarak verilmiştir. Ayrıca her bir sorunun altında temaların ve kodların oluşmasına esas teşkil eden katılımcı ifadelerinin bir kısmına yer verilmiştir. Bunun yanı sıra verilerden elde edilen öğretmenleri yeşil davranışları gerçekleştirmeye iten güdüler Şekil 1'de, yeşil davranışları özendirmek için yapılabilecekler konusunda öğretmenlerin görüşlerini betimleyen özendirme faktörlerine Şekil 2' de yer verilmiştir. 


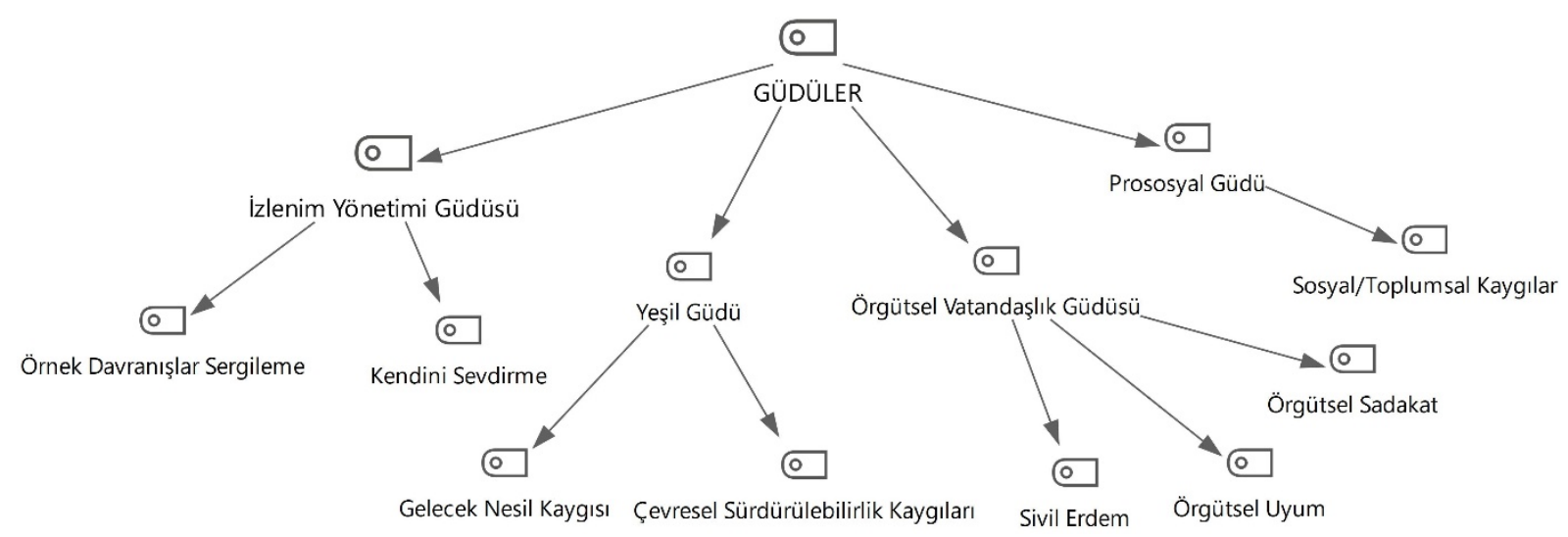

Şekil 1. Yeşil Davranışlara İten Güdüler

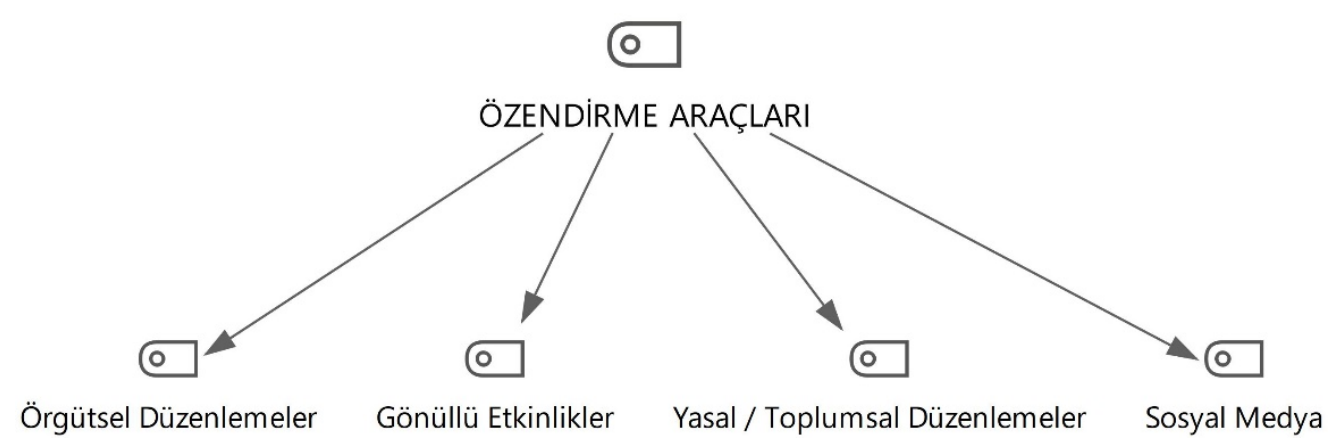

Şekil 2. Yeşil Davranışları Özendirme Araçları

\section{Araştırma Sorusu 1. Öğretmenlerin yeşil davranışları gerçekleştirme nedenleri nedir?}

Katılımcılara öncelikle en genel şekliyle çevrenin katılımcılar için ne ifade ettiği, onlar için ne anlama geldiği sorulmuştur. Burada amaç çevrenin katılımcılar için önemini anlamaya çalışmaktır. Daha sonra katılımcılara çevreye yönelik hangi tür davranışlarda bulundukları sorulmuştur. Bu sorunun amacı, katılımcıların gerçekleştirdikleri yeşil davranış türlerini ortaya çıkartmaktır. Son olarak böyle davranışlarda bulunmalarının nedenleri ve bu davranışların nasıl, ne şekilde etkili olacağı sorulmuştur. Bu sorunun amacı, katılımcıları yeşil davranışlara iten güdüleri ortaya çıkartmaktır. Soruların hazırlanış ve soruluş şekli nitel araştırma yöntemlerine uygun şekilde en genel şekilden araştırma amacını ortaya çıkaracak şekilde özele doğru hazırlanmıştır. Şekil 1'de sunulduğu gibi, bu konuda izlenim yönetimi güdüsü, yeşil güdü, örgütsel vatandaşlık güdüsü ve prososyal güdü olmak üzere dört tema ortaya çıkmıştır. Katılımcıların ifade sıklığına göre temalara Tablo 2' de yer verilmiştir.

Tablo 2. Katılımcıları Yeşil Davranışlara İten Güdüler

\begin{tabular}{|l|r|r|r|}
\hline \multicolumn{1}{|c|}{ Güdüler } & Belgeler & Yüzde & Yüzde (geçerli) \\
\hline İzlenim Yönetimi Güdüsü & 19 & 95,00 & 95,00 \\
\hline Yeşil Güdü & 9 & 45,00 & 45,00 \\
\hline Örgütsel Vatandaşlık Güdüsü & 7 & 35,00 & 35,00 \\
\hline Prososyal Güdü & 6 & 30,00 & 30,00 \\
\hline Kodlanmış Belgeler & 20 & 100,00 & 100,00 \\
\hline Kodlanmamış Belgeler & 0 & 0,00 & 0,00 \\
\hline Analiz Edilen Belgeler & 20 & 100,00 & $100,00-$ \\
\hline
\end{tabular}

Her bir temanın ayrıntıları şu şekildedir:

\section{İzlenim Yönetimi Güdüsü}

Katılımcılara sergiledikleri yeşil davranışların nedenleri sorulduğunda katılımcıların büyük çoğunluğunun (\%95) izlenim yönetimi olarak yorumlanan ifadelerde bulunduğu görülmüştür. İzlenim yönetimi ile ilgili 
yazın incelendiğinde katılımcıların ifadeleri, izlenim yönetimi taktiklerinden "örnek davranışlar sergileme" ve "kendini sevdirme" kodları altında toplanmıştır.

Öğretmenlerin büyük çoğunluğu yeşil davranışları öğrencilerini etkilemek ve onlara örnek olmak amaciyla gerçekleştirdiklerini söylemişlerdir. Bu söylemler "örnek davranışlar sergileme" kodu altında betimlenmiştir ve bu konudaki bazı katılımcı ifadeleri şu şekildedir:

Ö5: Tabi ki öğrencilerin rol model aldığı kişiler olarak bu tür yeşil davranışları sergilemek çocukları inanılmaz etkiler. Siz duyarlılık gösterip ışıkları kapatırsanız öğrenciler de bir süre sonra bu davranışı alışkanlık haline getirirler. Ancak siz bu konuda duyarsız olursanız özellikle küçük yaş grubu öğrenciler bunun doğru olduğunu düşünürler.

Ö10: Öğrencilerim için benim yaptığım her hareket onlara örnek olur. Çünkü öğretmenlerinin yaptı̆̆1 her hareket doğrudur onların yaşındaki çocuklar için. Anne babalarından çok bizi görüyorlar, bizimle birlikteler. Ben akan bir musluğu kapatırsam, boşa yanan bir lambayı söndürürsem öğrencilerim bundan daha fazla etkilenir. Derslerde ne kadar anlatırsak anlatalım öğrencilerimiz ne yaptı̆̆ımıza bakar.

Ö15: Bir öğretmenin çöpü yerden alıp çöpe atması onlara nasihat etmekten daha ekili olduğunu düşünüyorum.

Ö18: Bir öğrencinin karşısında kullanılmış kâğıdı geri dönüşüm kutusuna atarsam veya açık kalmış bir musluğu kapatırsam o öğrencim benim bu davranışı neden yaptığımı mutlaka sorgulayacağını düşünüyorum.

Katılımcı bazı öğretmenlerin yeşil davranışları veliler ve ziyaretçiler üzerinde iyi izlenim bırakmak için gerçekleştirdiğini anlattıkları görülmüştür. "Kendini sevdirme" olarak kodlanan bu konudaki bazı katılımcı ifadeleri şu şekildedir:

Ö13: Bu tutumun okula maddi açıdan fayda sağlayacağını düşünüyorum. Öğrenci ve velilere olumlu izlenimler bırakacağını, temiz bir çevrede daha sağlıklı vakit geçireceğimize inanıyorum.

Ö16: Özel bir okul olması sebebiyle okulu ziyaret eden kişilerde olumlu izlenimler bırakmayı amaçliyoruz.

\section{Yeşil Güdü}

Bazı katılımcılar anlatımlarında yeşil davranışları "çevresel sürdürülebilirliğe katkı sağlamak", "gelecek nesillere sağlıklı ve temiz çevre bırakmak" için yaptığını ifade etmişlerdir. Yeşil güdü olarak betimlenen bu tema katılımcı ifade sıklığına göre ikinci sırada yer almaktadır (\%45). Bununla ilgili bazı katılımcı anlatımları şu şekildedir:

Ö5: Yaşadığım çevre bence hayatımdaki en önemli faktörlerden biridir. Yaşadığım yeri seçerken baktığım ilk şey yaşayacağım evin çevresidir. Sabah penceremi açtı̆̆ımda yemyeşil bir manzaranın beni karşılaması çok önemlidir.

Ö6: Gereksiz yere elektrik, su kullanmam, elimde bir çöp varsa bir çöp konteynırı bulana kadar onu elimde tutarım, hiç denk gelmezsem eve kadar götürür evde atarım. Bunun sebebi çok iyi bir çevreci olmam değil ama en azından elimden bu geliyor. İçerisinde bulunduğum ortam daha temiz ve güzel görünebilir.

Ö6: Yaşadığımız çevreyi en azından şu anki hali ile tutabilmek, daha kötüye gitmesini engellemek, yetişen nesillere daha güzel yaşam alanları sunabilmek amaçlanmalıdır ama maalesef ki özellikle okul içerisinde bu tür davranışlara pek rastlayamadım henüz.

Ö10: Çevre benim ve çocuklarımın geleceğidir. Sağlıktır çevre. Bazen çevreyi kirlettiklerini görüyorum bazen uyarıyorum eğer uyarabileceksem ama bazen de doğrusu hiçbir şey yapamıyorum söylemiyorum kimi zaman da kendim gidip temizliyorum.

\section{Örgütsel Vatandaşlık Güdüsü}

Katılımcı anlatımlarının incelendiğinde bazı katılımcıların (\%35) yeşil örgütsel davranışları örgütün fonksiyonlarını, amaçlarını yerine getirmeyi desteklemek için gönüllü olarak gerçekleştirdiği görülmüştür. Örgütsel vatandaşlık güdüsü olarak betimlenen bu tema altında katılımcı ifadeleri "örgütsel sadakat", 
"örgütsel uyum" ve "sivil erdem" kodları altında toplanmıştır. Kodlamalara esas olan bazı katılımcı söylemleri şu şekildedir:

Ö1: Kendini düşünen bir insan modeli olamaz. Bir kurumda çalışılıyorsa o kurumun ekmeğini yiyorsa o kuruma her türlü gelebilecek sıkıntılara göğüs germelidir ve sadakat gösterilmelidir.

Ö11: Ben fen bilgisi öğretmeniyim. Ders konularımın içinde çevre var zaten. Bu yüzden benim için böyle davranışlar sergilemek aynı zamanda öğretmen olarak görevim.

Ö13: Ayrıca bizim okulumuz çevre odaklı bir okul, kurumsal görevlerimiz içinde de var misyonumuz yani okulumuzun adı bile çevreyle ilgili bu da bizim için ayrıca görevimiz oluyor.

Ö18: En başta çalışma arkadaşlarımın eğitimci olmaları yeşil davranışlar sergilemelerindeki en büyük neden diyebilirim... Beni bu kadar duyarlı yapan nedenlerden biri çalıştığım kurumun yani okulumun çevre konusunda duyarlı olması. Her yıl olduğu gibi bu yılda okulumuz Milli Eğitim Bakanlığı tarafından çevreci bir okul seçilerek beyaz bayrak almıştır.

Ö20: Kurumda aldığımız ortak kararlar var bu kararlara uymak için bu davranışları yapmamız söz konusu.

\section{Prososyal Güdü}

Katılımcıları yeşil davranış gerçekleştirmeye iten güdü olarak betimlenen son tema prososyal güdülerdir. Bazı katılımcıların (\%30) yeşil davranışları toplumsal ve sosyal ekogirişim olarak gördükleri, toplumsal çıkarlar nedeniyle böylesine davranışları gerçekleştirdiği görülmüştür. "sosyal/toplumsal kaygılar" olarak kodlanan katılımcı ifadelerinden bazıları şu şekildedir:

Ö8: Toplumsal değerlerin işleyiş̧i, devamlılığı için çevre ve çevresel davranışlar önemlidir.

Ö9: Geri dönüşüme önem vermek, gereksiz ışıkları kapatmak oldukça önemlidir. Çünkü ileride oluşabilecek sorunların önüne geçmek için bir adımdır. Herkes bu konuda dikkatli olursa problemler azaltılabilir.

\section{Araştırma Sorusu 2. Öğretmenlerin yeşil davranışlarını arttırmak için neler yapılabilir?}

Katılımcı öğretmenlerin yeşil davranışları neden gerçekleştirdikleri konusunda görüşleri alındıktan sonra, yeşil davranışların kendi kurumlarında arttırılması için neler yapılabileceği sorulmuştur. Bu sorunun amacı bu güdüleri harekete geçirmek için neler yapılabileceğini katılımcıların bakış açıları ile ortaya çıkartabilmektir. Şekil 2'de sunulduğu gibi bu konuda örgütsel düzenlemeler, gönüllü etkinlikler, yasal toplumsal düzenlemeler ve sosyal medya olmak üzere dört tema betimlenmiştir. Katılımcıların ifade sıklığına göre özendirme araçları Tablo 3'de yer almaktadır.

Tablo 3. Yeşil Örgütsel Davranışları Özendirme Araçları

\begin{tabular}{|l|r|r|r|}
\hline \multicolumn{1}{|c|}{ Özendirme Araçları } & Belgeler & Yüzde & $\begin{array}{c}\text { Yüzde } \\
\text { (Geçerli) }\end{array}$ \\
\hline Örgütsel Düzenlemeler & 8 & 40,00 & 57,14 \\
\hline Gönüllü Etkinlikler & 7 & 35,00 & 50,00 \\
\hline Yasal / Toplumsal Düzenlemeler & 2 & 10,00 & 14,29 \\
\hline Sosyal Medya & 1 & 5,00 & 7,14 \\
\hline Kodlanmış Belgeler & 14 & 70,00 & 100,00 \\
\hline Kodlanmamış Belgeler & 6 & 30,00 & - \\
\hline Analiz Edilen Belgeler & 20 & 100,00 & - \\
\hline
\end{tabular}

Her bir temanın ayrıntıları şu şekildedir:

Örgütsel Düzenlemeler

Katılımcı öğretmenlere yeşil davranışları arttırılabilmesi için neler yapılabileceği sorulduğunda en fazla ifade edilen (\%40) araç örgütsel düzenlemeler olmuştur. Bu konuda bazı katılımcı ifadeleri şu şekildedir: 
Ö2: Disiplinin tam uygulanmasını isterdim, çevreye zarar veren uygunsuz davranışlar yeterince cezalandırılmadığı için tekrarlanmaya devam ediyor.

Ö3: Bu konuda kurumsal olarak hareket etmenin yararı elbette yadsınamayacaktır.

Ö19: Gereksiz tüketimin (kâğıt, gıda, elektrik, su, ısınma-soğutma vb.) önlenmesine yönelik kurallar ve önlemler olmasını isterdim. Bunun etkili olacağını düşünüyorum.

Ö20: Ara ara öğrencilerin çevre sorunlarıyla yüzleştirilmesi gerektiğini düşünüyorum. Örneğin bir gün suların kesilmesi yapılarak çocukların susuzluğun ne derece önemli bir kaynak olduğunu fark ettirmek. Ağacın dalını kırdığı zaman yaptığı yanlış davranış için öğrencinin bedel ödemesini sağlarım, mesela ağaç dikmesini sağlama gibi... kurum çalışanları işe alınırken işe alımda çevre duyarlılığı mülakat gündemi olmalıdır.

\section{Gönüllü Etkinlikler}

Yeşil davranışların özendirilebilmesi için bazı katılımcı öğretmenlerin (\%35) ifade ettiği diğer araç okullarda gönüllü etkinliklerin düzenlenmesidir. Katılımcıların bununla ilgili bazı söylemleri şu şekildedir:

Ö3: Ancak toplumsal farkındalık projelerine aktif katılımın daha fazla olması gerektiğini söyleyebilirim. Veli-okul buluşmalarında da bu konuda ek bir başlık açılabileceğini düşünüyorum.

Ö6: Öğrencilerle birlikte ağaç dikme etkinlikleri, atık pil toplama, çevreyi temizleme, çöplerden arındırma, küresel ısınmayı önlemek amacıyla geliştirilebilecek proje yarışmaları gibi etkinler yapılabilir. Bu tür etkinlikler uygulaması kolay ve öğrencilerde çevre bilinci uyandırmada ilgi çekebilecek etkinlikler olduğunu düşünüyorum.

Ö17: Sınıf öğretmenliği zümresi aldığı kararlar gereğince israfı ve çevre kirliliğini önlemek adına grupça davranışlar sergilemektedir. Öğrencilerimizin de bu bilinci kazanabilmeleri için haftanın en temiz sınıfını seçmek gibi farkındalık yaratıcı etkinlikler yapılmaktadır.

\section{Yasal/Toplumsal Düzenlemeler}

Katılımcı öğretmelerin ifade ettiği diğer özendirme aracı yasal ve/veya toplumsal düzenlemeler yapılmasıdır. Bu konudaki bazı söylemler şu şekildedir:

Ö3: Toplumsal farkındalık projelerinin bu kapsamda çok daha aktif bir şekilde oluşturulması ve yürütülmesi gerekmektedir...

Ö13: Ancak bu davranışları kendisine bir yaptırımı yoksa umursamıyor ve ilgisiz kalıyorlar.

\section{Sosyal Medya}

Son olarak araştırmaya katılan Ö20 sosyal medyanın kullanılmasının yeşil örgütsel davranışları arttıracağını ifade etmiştir. Katılımcının bu konudaki söylemi şu şekildedir; "akılda kalabilecek videoların hazırlanılması sosyal medya kullanılarak önemli olacaktır".

\section{Tartışma ve Sonuç}

Çevresel sürdürülebilirlik 21. yüzyılda örgütlerin ayakta kalabilmelerinde önemli bir boyutu temsil etmektedir. Örgütlerin bu yöndeki hedeflerine ulaşmalarında proaktif çevresel davranışın işyerine özgü biçimi olan "çalışan yeşil davranışı" kavramını ve bu davranışa neden olan güdüleyici faktörleri açıklamak faydalı olacaktır. Bireyler tarafından pek çok yeşil davranış ev ve iş ortamlarında sergilense de bulgular, bu iki farklı ortamda bireylerin farklı davrandığını göstermektedir. Özellikle işyerine özgü bir bağlam çerçevesinde, çalışan yeşil davranışı anlamanın önemi her geçen gün önemini artırmaktadır. Okullar da doğal çevre üzerindeki baskıyı azaltmada önemli bir role sahip örgütler olarak kabul edilmektedir. Zira okulların öğretmenleri de bir çalışan olarak doğal çevreyi olumlu etkileyecek veya çevreye yönelik olumsuz etkisini azaltacak davranışlar geliştirirler. Üstelik özel okul öğretmenleri istendik yeşil davranışlar konusunda rol model olabildikleri takdirde, okul öğrencileri de benzer olumlu davranışları gösterirler. Bir başka ifadeyle, bu öğretmenlerin hem çalıştığı örgüt yararına hem de eğiticilikleri ve öğrencilerine rol model olmaları yönüyle eğitim aracılığıyla gelecek nesillerin yararına yeşil davranışı teşvik etmesi çok daha öne çıkmaktadır. Bu tespitlerden hareketle, çalışmanın amacını öğretmenlerin yeşil örgütsel davranışları gerçekleştirmesine neden 
olan güdüleri belirlemek oluşturmuştur.

Çalışmanın ulaştığı ilk sonuç, katılımcıların yeşil davranışları izlenim yönetimi taktiği olarak kullanmasıdır. Öğretmenler, yaptıkları her davranışta öğrencileri için rol model olduklarını bu nedenle yeşil davranış gerçekleştirmeye özen gösterdiklerini çünkü öğrencileri için yaptıklarının söylediklerinden daha önemli olduğunu ifade etmişlerdir. Bu ifadelerinden hareketle, öncelikli olarak öğretmenlerin yeşil örgütsel davranışları öğrenciler üzerinde "örnek davranışlar sergileme" taktiği olarak kullandığı görülmektedir. Bunun öğretmenlik mesleğine özgü bir durum olduğu düşünülmektedir. Bunun yanı sıra öğretmenlerin veli ve ziyaretçiler üzerinde "kendini sevdirme" taktiği olarak, iyi bir izlenim bırakmak için yeşil örgütsel davranışları gerçekleştirdikleri bulunmuştur. Araştırmanın bu bulgusunun araştırma alanına özgü olduğu düşünülmektedir. Çünkü katılımcı öğretmenler çalıştıkları kurum özel okul olduğu için ziyaretçiler üzerinde iyi bir izlenim bırakmaları gerektiğini düşünmektedirler. Çalışmanın bu bulguları yazında daha önceden yürütülmüş bazı çalışmaların sonuçları ve ön görüleriyle benzerlik göstermektedir. Örneğin Araujo (2014: 7) izlenim yönetiminin çalışan yeşil davranışını güdülemede önemli bir etken olduğunu önermiş, itibarıyla ilgili kaygısı yüksek oldukça çalışanların ister işiyle ilgili ister proaktif olsun imajını yükseltecek şekilde çalışacağını öne sürmüştür. Araujo (2014: 8) çalışanların yeşil davranış sergilemesinin ya görevi olduklarını düşünmesi yönündeki inançları dolayısıyla (örnek davranışlar sergileme gibi) ya da yeşil davranışlar sergileyerek olabilecek sosyal kazanımlar dolayısıyla (kendini sevdirme gibi) güdülenebileceklerini öne sürmüştür. Buna göre, çevre dostu davranış sergileyen öğretmen kendini sevdirerek olumlu bir itibar kazanabilecek ve böylece imajinı artırabilecektir.

Katılımcıları yeşil davranışlara yönlendiren diğer bir güdüyü yeşil güdü oluşturmuştur. Alan yazında ilk kez yer aldığı düşünülen bu güdü katılımcıların çevresel sürdürülebilirlik ve gelecek nesil kaygıları ile ilgili anlatımlarından elde edilmiştir. Temanın yeşil güdü olarak betimlenmesinin nedeni katılımcıların başka bir çıkar gözetmeksizin tamamen çevreyi düşünerek güdülenmesidir. Bu nedenle bu güdünün "yeşil güdü" olarak betimlenmesi araştırmacılar tarafından uygun görülmüştür. Çalışmanın "yeşil güdü" tanımlaması Klein'in (2015: 24) "İçsel Çevresel Güdüler" başlığını oluşturan "çevresel fayda" alt temasına benzerlik göstermiştir. Klein'e göre çevresel fayda güdüsü; kişilerin içsel açıdan doğal kaynakları korumaya yardım etmeye ve çevre kalitesini artırmaya ilgi duymasına işaret eder. Çevre odaklı değerler, biyosferik kaygılar veya koruyucu etik gibi çevresel kaygıların kişiler için önemli olması sonucunda yeşil davranışlar sergilenir hale gelir.

Araştırmada elde edilen diğer bulgu örgütsel vatandaşlı güdüsüdür. Bu bulgu, katılımcıların yeşil davranışları örgüt amaçlarını ve örgüt faaliyetlerini desteklemek için gönüllü olarak gerçekleştirdikleri yönündeki ifadelerinden elde edilmiştir. Örgütsel vatandaşlık güdüsü altında, örgütsel kurallar gereği bu davranışların gerçekleştirilmesi "örgütsel uyum" boyutunda, örgütün amaçlarını ve misyonunu gerçekleştirmek üzere yapılması "örgütsel sadakat" boyutunda ve bütün olarak okulun imajı, görünüşü için gerçekleştirilmesi ise "sivil erdem" boyutunda yer almaktadır. Çalışmanın bu yöndeki bulgusu önceki dönemde yürütülmüş bazı çalışmaların sonuçlarıyla örtüşme sağlamıştır. Şöyle ki; Klein'in (2015: 24) "İçsel Çevresel Güdüler" sınıflamasının ikinci alt temasını "diğerkâmlık" oluşturmuştur. Bu alt tema, diğer kişilerin faydasına olacak şekilde diğer kişilere yardım etme çevresel davranışlarca işlev gören önemli bir fonksiyonu temsil eder. Diğerkâmcı güdüler gelecek nesiller için kaynakları koruma ve toplumun bireylerine yardım etme gibi ideallerle ölçülen güdüleri ifade eder.

Katılımcı öğretmenleri yeşil örgütsel davranış gerçekleştirme konusunda harekete geçiren son güdü, prososyal güdüdür. Bu güdü, çevresel sürdürülebilirlik, iyi izlenim, örnek olma veya örgütsel hedeflere ulaşma dışında tamamen toplumsal ve sosyal kurallar ve kaygılar nedeniyle yeşil davranışların gerçekleştirilmesini ifade etmektedir. Çalışmanın bu yöndeki bulgusu Araujo'nun (2014: 13) izlenim yönetiminin çalışan yeşil davranışı güdüleyeceğini göz önüne alarak bu ilişkiyi "işle ilgili" ve "proaktif çalışan yeşil davranışları" şeklindeki ayrımını desteklemektedir. O'na göre proaktif çalışan yeşil davranışı için amaç farklılık gösterir. Davranışın gönüllü olarak gerçekleştiği bu davranışta çalışan için bir kayıp söz konusu olmaz. Ancak bu davranış sergilenince bir kazanım doğar. Dolayısıyla böyle bir davranış "çevreye yönelik örgütsel vatandaşlık davranışı" ile benzerdir. Çevreye yönelik örgütsel vatandaşlık davranışı, "örgüt ortamında örgütün gerek duymadığı ve ödüllendirmediği isteğe bağlı eylemlerle ilgili çevresel çabalar" olarak tanımlanır (Daily vd., 2009: 246) ve bu kavram bir bireyin yardımsever, iş birliği veya sorumlu davranışlar gösterme eğilimidir (Bolino, 1999: 85) ve çevreye yardım etmeyle ilişkilidir. Ayrıca çalışmanın bu yöndeki bulgusu örgütsel vatandaşlık davranışına yönelik üç güdü faktörünü (prososyal değerler, izlenim yönetimi ve örgütsel kaygı) 
tanımlayan Rioux ve Penner'in (2001: 1307) prososyal değerlerine benzerlik göstermektedir.

Çalışmada belirlenen diğer araştırma sorusu, öğretmenlerin yeşil örgütsel davranışlarını arttırmak için neler yapılabileceğinin belirlenmesidir. Bu kapsamda elde edilen ilk bulgu, hangi güdü ile harekete geçilmiş olursa olsun katılımcı öğretmenlerin büyük çoğunluğu yeşil örgütsel davranışların arttırılmasında en etkili aracı örgütsel düzenlemeler olarak görmektedir. Buna göre, örgüt içinde kuralların belirlenmesi, denetleme ile ödül ve ceza mekanizmalarının oluşturulması ve bunların etkinliğinin sağlanması, işe alım sınavlarında yeşil davranışlar konusunun belirtilmesi gibi düzenlemeler yeşil örgütsel davranışları arttıracaktır. Gönüllü etkinlikler yeşil örgütsel davranışların arttırılması için yapılabilecek ikinci araçtır. Öğretmenlerin çevresel projeler yapmaları, zümreler halinde hareket edilmesi, öğretmen ve öğrencilere yönelik çevresel eğitimlerin verilmesi gibi girişimler yeşil örgütsel davranışları arttıracaktır. Bunun yanı sıra çevrenin korunmasına yönelik yasal mevzuatın geliştirilmesi, toplumsal normların etkinliğinin arttırılması da yeşil örgütsel davranışları arttıracaktır. Bu konuda elde edilen son bulgu örgütlerde yeşil örgütsel davranışları özendirme aracı olarak sosyal medyanin kullanılmasidır.

Ulusal yazında oldukça az sayıda olan örgütsel yeşil davranışlar konusunda, bu çalışmada elde edilen bulgularla örgüt içindeki yeşil davranışların neden gerçekleştirildiği ve örgütlerin çevre dostu davranışlarının arttırılması için neler yapılabileceği noktasında uygulayıcılara katkı sağlanması düşünülmektedir. Bunun yanı sıra, çalışmanın yazında örgütsel yeşil davranışlar konusunda çalışma yapan araştırmacılar için kaynak teşkil edebileceği de düşünülmektedir. Ayrıca elde edilen sonuçların çalışma alanının kendine özgü niteliklerinden kaynaklanıp kaynaklanmadığı da ileride yapılacak araştırmalarla denenebilir, özellikle öğretmenlik meleğine ve çalışılan kuruma özgü olduğu düşünülen izlenim yönetimi taktikleri bu kapsamda denenebilir. Çünkü örnek davranışlar sergileme taktiği konusundaki ifadelerde mesleğe vurgu yapıldığı, kendini sevdirme taktiğinde ise özel okul olmalarının vurgulandığı görülmektedir. Dolayısıyla farklı alan ve sektörlerde çalışan örgüt üyeleri hatta aynı mesleği yapmalarına rağmen devlet okullarında görev yapan öğretmenler farklı güdülerle hareket edebilirler. Bu durum gelecekte yapılacak nitel (veya nicel) çalışmalarda araştırılabilir. Gelecekte yapılacak çalışmalar açısından yine bu çalışmada göz ardı edilen demografik faktörler çalışılabilir.

\section{Kaynakça}

Aguinis, H., ve Glavas, A. (2013). Embedded versus peripheral corporate social responsibility: psychological foundations. Industrial Organizational Psychology, 6, 314-332.

Araujo, F. F. (2014). Do 1 look good in green?: A conceptual framework integrating employee green behavior, impression management and social norms. Amazon, Organizations and Sustainability, 6(2), 7-23.

Bansal, P. ve Roth, K. (2000). Why companies go green: a model of ecological responsiveness. Academy of Management Journal, 43(4), 717-736.

Bartlett, D. (2011). Introduction: the psychology of sustainability in the workplace, , D. Bartlett (Ed.), The Psychology of Sustainability in the Workplace (1-5). London: British Psychological Society.

Benn, S., Dunplay, D. ve Griffiths, A. (2014). Organizational change for corporate sustainability. New York, NY: Routledge.

Bissing - Olson, M. J., Iyer, A., Fielding, K. S. ve Zacher, H. (2013). Relationships between daily affect and proenvironmental behavior at work: the moderating role of pro-environmental attitude. Journal of Organizational Behavior, 34(2), 156-175.

Blok, V., Wesselink, R., Studynka, O. ve Kemp, R. (2015). Encouraging sustainability in the workplace: a survey on the pro-environmental behavior of university employees. Journal of Cleaner Production, 106, 55-67.

Boiral, O. , Paille, P. (2012). Organizational citizenship behaviour for the environment: measurement and validation. Journal of Business Ethics, 109(4), 431-445.

Boiral, O., Paille, P. ve Raineri, R.N. (2015). The nature of employees' pro-environmental behaviors, in J.L. Robertson ve J. Barling (Eds.), The Psychology of Green Organizations, (12-33), Oxford University Press, NY: USA. 
Bolino, M. (1999). Citizenship and impression management: good soldiers or good actors. Academy of Management Review, 2481), 82-98.

Borman, W. C. ve Motowidlo, S. J. (1993). Expanding the criterion domain to include elements of contextual performance, in N. Schmitt ve W. C. Borman (Eds.), Personnel Selection in Organizations, (71-98), San Francisco, CA: Jossey-Bass.

Bramston, P., Pretty, G. ve Zammit, C. (2011). Assessing environmental stewardship motivation. Environment and Behavior, 43(6), 776-788.

Daily, B. F., Bishop, J. W. ve Govindarajuli, N. (2009). A conceptual model for organizational citizenship behavior directed toward the environment. Business \& Society, 48(2), 243-256.

Denzin, N. K. ve Lincoln, Y. S. (2005). The Sage Handbook of Qualitative Research. 3rd edn. Sage, London.

De Young, R. ve Kaplan, S. (1986). Conservation behavior and the structure of satisfactions. Journal of Environmental Systems, 15(3), 223-292.

Dedeoğlu, T., Kaya, Y. ve Özdevecioğlu, M., (2016). Örgütsel davranış disiplini: gelişimi ve mevcut durumuna ilişkin değerlendirmeler, Turkish Journal of Management, 1(1), 33-40.

Dilchert, S., ve Ones, D. S. (2012). Measuring and improving environmental sustainability, in S. E. Jackson, D. S. Ones, ve S. Dilchert (Eds.), Managing HR for Environmental Sustainability, (187-221), San Francisco, CA: Jossey-Bass/Wiley.

D'mello, S., Ones, D.S., Klein, R.M., Wiernik, B.M. ve Dilchert, S. (2011). Green company rankings and reporting of pro-environmental efforts in organizations. Poster presented at the Annual Conference of the Society for Industrial and Organizational Psychology (Chicago, IL).

Homburg, A. ve Stolberg, A. (2006). Explaining pro-environmental behavior with a cognitive theory of stress. Journal of Environmental Psychology, 26(1), 1-14.

Hoş, R. (2012). The experiences of refugee students with interrupted formal education in an urban secondary school newcomer program, Unpublished PhD Thesis, Margaret Garner Graduate School of Education and Human Development, University of Rochester, Rochester, New York, ABD.

Kim, A., Kim, Y., Han, K., Jackson, S.E. ve Ployhart, R.E. (2017). Multilevel influences on voluntary workplace green behavior: individual differences, leader behavior and coworker advocacy. Journal of Management, 43(5), 1335-1358.

Klein, R. M. (2015). Employee motives for engaging in environmentally sustainable behaviors: a multi-study analysis. Doctoral Dissertation, Minnepolis, MN: University of Minnesota.

Kuş Saillard, E. (2010). Ruhsal hastalara yönelik damgalamaya ilişkin psikiyatrist görüşleri ve öneriler. Türk Psikiyatri Dergisi, 21(1), 14-24.

Lee, Y. J., De Young, R. ve Marans, R. W. (1995). Factors influencing individual recycling behavior in office settings: a study of office workers in Taiwan. Environment and Behavior, 27(3), 380-403.

Lo, S.H., Peters, G.-J. Y. ve Kok, G. (2012). Energy - related behaviors in office buildings: a qualitative study on individual and organisational determinants. Applied Psychology: An International Review, 61(2), 227249.

Merriam, S. B. (2013). Nitel Araştırma Desen ve Uygulama İçin Bir Rehber. (Çev. Selahattin Turan), Ankara: Nobel Akademik Yay. Eğt. Dan. Tic. Ltd. Şti.

Mesmer-Magnus, J., Viswesvaran, C. ve Wiernik, B. M. (2012). The role of commitment in bridging the gap between organizational sustainability and environmental sustainability, in S. E. Jackson, D. S. Ones, ve S. Dilchert (Eds.), Managing HR for Environmental Sustainability, (155-186), San Francisco, CA: Jossey-Bass/Wiley.

Morrow, S. L. ve Smith, M. L. (2000). Qualitative research for counseling psychology. In S. D. Brown \& R. W. Lent (Eds.), Handbook of counseling psychology (3rd ed., pp. 199-230). New York: Wiley. 
E. Bayrakçı - M. Dinç 12/1 (2020) 188-201

Norton, T.A., Parker, S.L., Zacher, H. ve Ashkanasy, N.M. (2015). Employee green behavior: a theoretical framework, multilevel review and future research agenda. Organization \& Environment, 28(1), 103-125.

OECD, U. E. (2002). Data collection on education systems: Definitions, explanations and instructions. Retrieved 15.12.2019 from http://www.oecd.org/edu/.

Ones, D. S. ve Dilchert, S. (2012a). Employee green behaviors, in S. E. Jackson, D. S. Ones, ve S. Dilchert (Eds.), Managing HR for Environmental Sustainability, (85-116), San Francisco, CA: Jossey-Bass/Wiley.

Ones, D. S. ve Dilchert, S. (2012b). Environmental sustainability at work: a call to action. Industrial And Organizational Psychology: Perspectives On Science And Practice, 5, 444-466.

Organ, D.W. (1997). Organizational citizenship behavior: It's construct clean-up time. Human Performance, 10(2), 85-97.

Özdemir, M. (2010). Nitel veri analizi: sosyal bilimlerde yöntembilim sorunsalı üzerine bir çalışma. Eskişehir Osmangazi Üniversitesi Sosyal Bilimler Dergisi, 11(1), 323-343.

Paile, P. ve Boiral, O. (2013). Pro-environmental behavior at work: Construct validity and determinants. Journal of Environmental Psychology, 36, 118-128.

Ramus, C. A. ve Steger, U. (2000). The roles of supervisory support behaviors and environmental policy in employee 'ecoinitiatives' at leading-edge European companies. Academy of Management Journal, 43(4), 605-626.

Rioux, S. M. ve Penner, L. A. (2001). The causes of organizational citizenship behavior: a motivational analysis. Journal of Applied Psychology, 86(6), 1306-1314.

Ryan, R. L., Kaplan, R. ve Grese, R. E. (2001). Predicting volunteer commitment in environmental stewardship programmes. Journal of Environmental Planning and Management, 44(5), 629-648.

Smith, A.M. ve O'sullivan, T. (2012). Environmentally responsible behavior in the workplace: an internal social marketing approach. Journal of Marketing Management, 28(3-4), 469-493.

Society For Human Resource Management (2011). Advancing Sustainability: HR's Role: A Research Report by SHRM, BSR and Aurosoorya. Alexandria, VA: SHRM.

Walcott, H. F. (1994). Transforming Qualitative Data: Description, Analysis and Interpretation. London: SAGE Publications.

Wiernik, B.M., Dilchert, S. ve Ones, D.S. (2016). Age and employee green behaviors: a meta-analysis. Frontiers in Psychology, 7(194), 1-15. 